\title{
Use of intermediate/small conductance calcium-activated potassium-channel activator for endothelial protection
}

\author{
Qin Yang, MD, PhD, ${ }^{\text {a,b }}$ Jun-Hao Huang, MPhil, ${ }^{\text {a }}$ Yu-Bun Man, MPhil, ${ }^{\mathrm{c}}$ Xiao-Qiang Yao, $\mathrm{PhD},{ }^{\mathrm{c}}$ and \\ Guo-Wei He, MD, PhD, DSc ${ }^{\mathrm{a}, \mathrm{b}, \mathrm{d}}$
}

Objectives: Endothelial dysfunction occurs in hypoxia-related states such as ischemic heart disease or heart surgery. Intermediate- and small-conductance calcium-activated potassium channels $\left(\mathrm{IK}_{\mathrm{Ca}}\right.$ and $\mathrm{SK}_{\mathrm{Ca}}$ ) are closely related to endothelium-dependent hyperpolarizing factor-mediated endothelial function. However, the status of these $\mathrm{K}_{\mathrm{Ca}}$ under hypoxia is unknown. We investigated whether endothelial dysfunction under hypoxic state is related to the alterations of $\mathrm{IK}_{\mathrm{Ca}}$ and $\mathrm{SK}_{\mathrm{Ca}}$ and whether use of $\mathrm{IK}_{\mathrm{Ca}} / \mathrm{SK}_{\mathrm{Ca}}$ activator may protect endothelium from hypoxia-reoxygenation injury.

Methods: Isometric tension measurement, patch-clamp technique, intracellular membrane potential recording, and molecular methods were used to study porcine coronary arteries and endothelial cells.

Results: Hypoxia-reoxygenation (60-30 minutes) decreased endothelium-dependent hyperpolarizing factormediated relaxation at normothermia in Krebs solution $(43.3 \% \pm 6.3 \%$ vs $82.3 \% \pm 2.9 \%)$ and in St Thomas' Hospital cardioplegic solution $(28.9 \% \pm 1.8 \%$ vs $78.1 \% \pm 3.0 \%)(P<.001)$ as well as at hypothermia in St Thomas' Hospital solution $(43.1 \% \pm 2.6 \%, P<.001)$. Hypoxia-reoxygenation markedly reduced endothelial $\mathrm{IK}_{\mathrm{Ca}}(2.8 \pm 0.6$ vs $6.9 \pm 0.6 \mathrm{pA} / \mathrm{pF})$ and $\mathrm{SK}_{\mathrm{Ca}}$ currents $(1.5 \pm 0.3$ vs $4.3 \pm 0.4 \mathrm{pA} / \mathrm{pF})(P<.05)$ and downregulated endothelial $\mathrm{IK}_{\mathrm{Ca}}$ expression. $\mathrm{IK}_{\mathrm{Ca}} / \mathrm{SK}_{\mathrm{Ca}}$ activator 1-ethyl-2-benzimidazolinone enhanced $\mathrm{K}^{+}$current in endothelial cells that was blunted by hypoxia. Further, 1-ethyl-2-benzimidazolinone restored $(P<.001)$ endothelium-dependent hyperpolarizing factor-mediated relaxation with hyperpolarization recovered from $6.0 \pm 0.3$ to $7.8 \pm 0.4 \mathrm{mV}(P<.05)$.

Conclusions: In porcine coronary arteries, hypoxia markedly reduced endothelial $\mathrm{K}^{+}$currents related to $\mathrm{IK}_{\mathrm{Ca}}$ and $\mathrm{SK}_{\mathrm{Ca}}$ with downregulation of protein expression and endothelium-derived hyperpolarizing factor function. $\mathrm{IK}_{\mathrm{Ca}} /$ $\mathrm{SK}_{\mathrm{Ca}}$ activator may preserve endothelium-dependent hyperpolarizing factor-mediated relaxation with enhancement of $\mathrm{K}^{+}$current in endothelial cells and cellular membrane potential hyperpolarization in smooth muscle cells and may become a new strategy to protect coronary endothelium in cardiac surgery or transplantation. (J Thorac Cardiovasc Surg 2011;141:501-10)

\section{Supplemental material is available online.}

\footnotetext{
From the Department of Surgery, ${ }^{\text {a }}$ The Chinese University of Hong Kong, Hong Kong; TEDA International Cardiovascular Hospital, ${ }^{\mathrm{b}}$ Medical College, Nankai University, Tianjin, China; the School of Biomedical Sciences, ${ }^{c}$ The Chinese University of Hong Kong, Hong Kong; and Providence Heart \& Vascular Institute, ${ }^{\mathrm{d}}$ Albert Starr Academic Center, Department of Surgery, Oregon Health and Science University, Portland, Ore.

This study was supported by grants from the Research Grant Council of the Hong Kong Special Administrative Region (Projects CUHK4651/07M \& CUHK4789/ 09M); Direct grant from CUHK 2041457 \& 2041561, Hong Kong; Tianjin Municipal Science \& Technology Commission (09ZCZDSF04200), Ministry of Science \& Technology, China (2009DFB30560; 2010CB529502), and the Providence St Vincent Medical Foundation, Portland, Ore.

Disclosures: Authors have nothing to disclose with regard to commercial support. Drs Yang and Huang are co-first authors.

Received for publication Nov 13, 2009; revisions received March 19, 2010; accepted for publication April 4, 2010; available ahead of print May 24, 2010.

Address for reprints: Qin Yang, MD, PhD, Department of Surgery, the Chinese University of Hong Kong, Block B, 5A, Prince of Wales Hospital, Shatin, NT, Hong Kong; or Guo-Wei He, MD, PhD, DSc, TEDA International Cardiovascular Hospital, Medical College, Nankai University, No. 61, the 3rd Ave, TEDA, Tianjin, 300457, China (E-mail: qyang@surgery.cuhk.edu.hk; gwhe@cuhk.edu.hk). $0022-5223 / \$ 36.00$

Copyright (c) 2011 by The American Association for Thoracic Surgery doi:10.1016/j.jtcvs.2010.04.005
}

Vascular endothelium releases nitric oxide $(\mathrm{NO}){ }^{1,2}$ prostacyclin $\left(\mathrm{PGI}_{2}\right),{ }^{3}$ and endothelium-derived hyperpolarizing factor $(\mathrm{EDHF})^{4}$ to regulate blood flow. The EDHFmediated relaxation and the associated hyperpolarization involve intermediate conductance calcium-activated $\mathrm{K}^{+}$channels $\left(\mathrm{IK}_{\mathrm{Ca}}\right)$ and small conductance calcium-activated $\mathrm{K}^{+}$channels $\left(\mathrm{SK}_{\mathrm{Ca}}\right)$ in the endothelial cell. ${ }^{5,6}$ In the vascular smooth muscle, various ion channels such as $\mathrm{Ba}^{2+}$-sensitive, inward rectifier $\mathrm{K}^{+}$channels (Kir), $\mathrm{Na}^{+}-\mathrm{K}^{+}$-adenosine triphosphatase, ${ }^{7}$ and large conductance calcium-activated $\mathrm{K}^{+}$channels $\left(\mathrm{BK}_{\mathrm{Ca}}\right)$ are involved. ${ }^{8}$ Intraluminal application of blockers of $\mathrm{IK}_{\mathrm{Ca}}$ and $\mathrm{SK}_{\mathrm{Ca}}$, charybdotoxin, and apamin blocked the EDHFmediated function, ${ }^{9}$ providing direct evidence for the involvement of endothelial $\mathrm{IK}_{\mathrm{Ca}}$ and $\mathrm{SK}_{\mathrm{Ca}}$ in this mechanism.

Ischemia-reperfusion (I-R) or hypoxia-reoxygenation (H-R) injury remains the major cause of cardiac dysfunction in ischemic heart disease and heart surgery including heart transplantation. I-R/H-R injury involves damage to myocytes as well as the coronary circulation (the vascular smooth muscle and the endothelium). Compared with vascular smooth muscle, endothelium is more vulnerable 


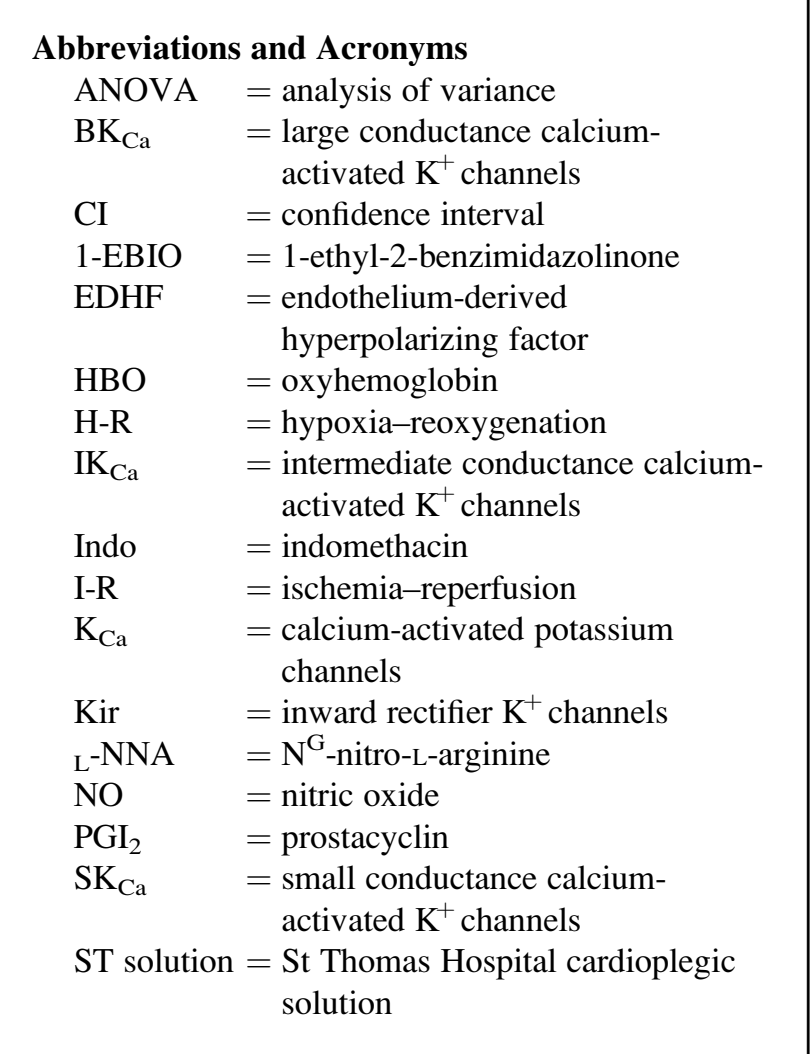

to I-R/H-R injury. ${ }^{10,11}$ Previous studies have demonstrated that alteration of endothelial function under $\mathrm{I}-\mathrm{R} / \mathrm{H}-\mathrm{R}$ is related not only to $\mathrm{NO}$ and $\mathrm{PGI}_{2}$, but also to EDHF mechanism. ${ }^{12-14}$ However, whether the change of EDHFmediated function under I-R/H-R is related to the changes of endothelial $\mathrm{IK}_{\mathrm{Ca}}$ or $\mathrm{SK}_{\mathrm{Ca}}$ remains unexplored. We tested the hypothesis that endothelial dysfunction owing to $\mathrm{H}-\mathrm{R}$ is related to the alterations of $\mathrm{IK}_{\mathrm{Ca}}$ and $\mathrm{SK}_{\mathrm{Ca}}$.

Furthermore, the role of $\mathrm{Ca}^{2+}$-activated $\mathrm{K}^{+}$channel $\left(\mathrm{K}_{\mathrm{Ca}}\right)$ in ischemic preconditioning, ${ }^{15}$ normal coronary arteriole, ${ }^{16}$ or smooth muscle ${ }^{17}$ has been reported. In one of our recent studies that mimics the clinical setting of heart surgery, $\mathrm{we}^{18} \mathrm{ob}-$ served the alterations of electrophysiologic properties and related function of smooth muscle $\mathrm{K}_{\mathrm{Ca}}$ in coronary arteries exposed to ischemia or hyperkalemia. However, with regard to coronary endothelium, although it has been reported that cardioplegia may damage coronary endothelial function ${ }^{19-22}$ and that microvascular dysfunction caused by cardioplegic arrest is likely in part owing to impaired function of $\mathrm{IK}_{\mathrm{Ca}}$ and $\mathrm{SK}_{\mathrm{Ca}}$ in the coronary microcirculation, ${ }^{23}$ the electrophysiologic mechanisms responsible for endothelial $\mathrm{IK}_{\mathrm{Ca}}$ and $\mathrm{SK}_{\mathrm{Ca}}$ dysfunction in I-R or H-R states are still largely unclear.

Our previous studies further demonstrated that in both large and microcoronary arteries, the impaired endothelial function is mainly related to the EDHF pathway, ${ }^{24-26}$ whereas NO release is not affected by $\mathrm{K}^{+}$at the concentration of $20 \mathrm{mmol} / \mathrm{L} .{ }^{27}$ Owing to the importance of endothelial $\mathrm{IK}_{\mathrm{Ca}}$ and $\mathrm{SK}_{\mathrm{Ca}}$ in the EDHF-mediated function, we therefore aimed to investigate whether endothelial dysfunction under hypoxic state is related to the alterations of $\mathrm{IK}_{\mathrm{Ca}}$ and $\mathrm{SK}_{\mathrm{Ca}}$ and whether use of $\mathrm{IK}_{\mathrm{Ca}}$ and $\mathrm{SK}_{\mathrm{Ca}}$ activator may protect porcine coronary endothelium from H-R injury. From this study, we suggested that a new strategy ${ }^{28}$ targeting on the endothelial $\mathrm{IK}_{\mathrm{Ca}}$ and $\mathrm{SK}_{\mathrm{Ca}}$ may be beneficial to the protection of endothelial function during heart surgery or transplantation.

\section{METHODS}

\section{Patch-Clamp Study of Endothelial $\mathrm{IK}_{\mathrm{Ca}}$ and $\mathrm{SK}_{\mathrm{Ca}}$ Currents}

Isolation and culture of endothelial cells. Fresh porcine hearts from the hog (either sex) weighing about $30 \mathrm{~kg}$, collected from a local slaughterhouse, were placed in a container filled with cold $\left(4^{\circ} \mathrm{C}\right)$ Krebs solution and immediately transferred to the laboratory. In brief, porcine large coronary arteries were dissected into $4 \times 4$-mm strips and treated with $0.2 \%$ collagenase (type I; Sigma Chemical Company, St Louis, Mo) in phosphate-buffered saline solution for 25 minutes at $37^{\circ} \mathrm{C}$. After the enzyme digestion, the suspension was centrifuged at $1600 \mathrm{rpm}$ for 5 minutes. The cells were resuspended in $5 \mathrm{~mL}$ culture medium containing 90\% Roswell Park Memorial Institute medium and 10\% fetal bovine serum with $100 \mathrm{U} / \mathrm{mL}$ penicillin and $100 \mu \mathrm{g} / \mathrm{mL}$ streptomycin. After a 1-hour incubation at $37^{\circ} \mathrm{C}$, the medium was replaced once to remove unattached cells. Attached endothelial cells were cultured in a humidified incubator with $5 \% \mathrm{CO}_{2}$ at $37^{\circ} \mathrm{C}$. For maintaining electrophysiologic properties of isolated coronary endothelial cells, only primary cells were used for experiments.

Patch-clamp recording of $\mathrm{IK}_{\mathrm{Ca}}$ and $\mathrm{SK}_{\mathrm{Ca}}$ currents. $\mathrm{K}^{+}$ currents in porcine primary endothelial cells were measured at room temperature $\left(20^{\circ} \mathrm{C}-24^{\circ} \mathrm{C}\right)$ by whole-cell patch-clamp technique. Pharmacologic blockers, iberiotoxin for $\mathrm{BK}_{\mathrm{Ca}}$, charybdotoxin for $\mathrm{IK}_{\mathrm{Ca}}$, and apamin for $\mathrm{SK}_{\mathrm{Ca}}$ were used to differentiate the role of $\mathrm{BK}_{\mathrm{Ca}}, \mathrm{SK}_{\mathrm{Ca}}$ and $\mathrm{IK}_{\mathrm{Ca}} \cdot{ }^{29,30}$ The effect of $\mathrm{IK}_{\mathrm{Ca}} / \mathrm{SK}_{\mathrm{Ca}}$ activator 1-ethyl-2-benzimidazolinone (1-EBIO) on the $\mathrm{K}^{+}$current was also examined.

Hypoxia exposure of endothelial cells. The primary culture of endothelial cells (seeded on glass coverslips) was placed in our renovated plastic cover-sealed myograph chamber filled with Krebs solution, and the solution was continuously bubbled with $95 \% \mathrm{~N}_{2}-5 \% \mathrm{CO}_{2}{ }^{12} \mathrm{Po}_{2}$ change was monitored by an Oxygen Meter (model 781; Strathkelvin Instrument, Glasgow, Scotland, United Kingdom). The effectiveness of the device for hypoxia exposure has been demonstrated in our previous studies. The hypoxia in these experiments was attempted to approximate that in relaxation studies (1 hour). Endothelial cells were exposed to hypoxia before being transferred to the experimental chamber for current recording. 


\section{Protein Expression of Endothelial $\mathrm{IK}_{\mathrm{Ca}}$-Western Blot Analysis}

Endothelial cells from porcine coronary arteries were scraped from the luminal surface by a clean scalpel blade. ${ }^{31}$ Whole cell proteins were extracted from endothelial cells and separated by an $8 \%$ sodium dodecysulfate-polyacrylamide gel. Separated proteins were electro-transferred onto a polyvinylidene difluoride membrane and probed with rabbit-raised anti- $\mathrm{K}_{\mathrm{Ca}} 3.1$ primary antibodies followed by anti-rabbit immunoglobulin antibodies (Alomone, Jerusalem, Israel). Immunostained protein bands were visualized by using electrochemoluminescent analysis system.

\section{EDHF-Mediated Responses}

Isometric force study. Isometric forces of coronary microarteries (200-450 $\mu \mathrm{m})$ were studied in a myograph. The details of preparation, mounting, and normalization of microarteries have been published in our previous studies. ${ }^{12,27,32,33}$

Membrane potential measurement. The membrane potential of a single smooth muscle cell was measured by an intracellular microelectrode as previously described. ${ }^{25,33}$

Hypoxia. During experiments, the solution was aerated with a gas mixture of $95 \% \mathrm{O}_{2}-5 \% \mathrm{CO}_{2}$ (normoxia). Hypoxic condition was induced by switching bubbling gas from $95 \% \mathrm{O}_{2}-5 \% \mathrm{CO}_{2}$ to $95 \% \mathrm{~N}_{2}-5 \% \mathrm{CO}_{2}$ (hypoxia, $\mathrm{PO}_{2}<5 \mathrm{~mm} \mathrm{Hg}$ ) in the plastic cover-sealed chamber. $\mathrm{PO}_{2}$ was measured by an Oxygen Meter. This method has been demonstrated to be successful in our laboratory. ${ }^{12}$

EDHF-mediated relaxation and hyperpolarization of the vascular smooth muscle. EDHF-mediated relaxation and hyperpolarization were studied with the presence of indomethacin (Indo, $7 \mu \mathrm{mol} / \mathrm{L}), \mathrm{N}^{\mathrm{G}}$-nitro-L-arginine $\left(\mathrm{L}_{\mathrm{L}}-\mathrm{NNA}\right.$, $300 \mu \mathrm{mol} / \mathrm{L}$ ), and oxyhemoglobin $(\mathrm{HbO}, 20 \mu \mathrm{mol} / \mathrm{L})$, as $\mathrm{we}^{33}$ demonstrated previously. In the relaxation studies, cumulative concentration-relaxation curves to bradykinin $(-10 \sim 6 \log \mathrm{M})$ were established in $\mathrm{U}_{46619}(10 \mathrm{nmol} / \mathrm{L})-$ precontracted microarteries. In the hyperpolarization studies, the cellular membrane potential in response to bradykinin $(0.1 \mu \mathrm{mol} / \mathrm{L})$ was recorded.

\section{Experimental Protocols}

Protocol I. Effect of $\mathrm{H}-\mathrm{R}$ on endothelial $\mathrm{IK}_{\mathrm{Ca}}$ and $\mathrm{SK}_{\mathrm{Ca}}$ currents-patch-clamp study. Coronary endothelial cells were exposed to either normoxia or hypoxia before the current recording. The whole-cell $\mathrm{K}^{+}$current was recorded in both groups of cells with further application of iberiotoxin, followed by charybdotoxin and then apamin. Changes in the charybdotoxin-sensitive $\mathrm{IK}_{\mathrm{Ca}}$ current and apamin-sensitive $\mathrm{SK}_{\mathrm{Ca}}$ current in the endothelial cells were further compared between the normoxic group and the hypoxic group. The doses of iberiotoxin $(100 \mathrm{nmol} / \mathrm{L})$, charybdotoxin $(100 \mathrm{nmol} / \mathrm{L})$, and apamin $(100 \mathrm{nmol} / \mathrm{L})$ were chosen on the basis of previous patch-clamp studies on $\mathrm{K}_{\mathrm{Ca}} \cdot{ }^{29,30}$ In another set of experiments, $\mathrm{K}^{+}$currents in response to the challenge of 1 -EBIO $\left(600 \mu \mathrm{mol} / \mathrm{L}^{29,30}\right)$ were recorded in endothelial cells with or without hypoxic exposure.

Protocol II. Effect of $\mathrm{H}-\mathrm{R}$ on protein expression of endothelial $\mathrm{IK}_{\mathrm{Ca}}$ and the effect of 1-EBIO. Porcine coronary arteries were allocated to either normoxic group or hypoxic group with or without the presence of 1-EBIO before scraping of the luminal surface for collection of endothelial cells. In the hypoxic group, coronary arteries were placed in our renovated plastic cover-sealed myograph chamber filled with Krebs or Krebs containing 1-EBIO (600 $\mu \mathrm{mol} / \mathrm{L})$ and the solution was continuously bubbled with $95 \% \mathrm{~N}_{2}-5 \%$ $\mathrm{CO}_{2}$ to allow $\mathrm{Po}_{2}$ to drop below $5 \mathrm{~mm} \mathrm{Hg}$, as described in the "Methods" section. The endothelial cells were harvested after 1 hour of exposure to normoxia or hypoxia with or without 1-EBIO and the protein expression of $\mathrm{IK}_{\mathrm{Ca}}$ was determined.

Protocol III. Effect of H-R on contractility and EDHFmediated relaxation. Effect of $H-R$ on contractility. Two rings from the same microartery were allocated into 2 groups ( $\mathrm{n}=7$ in each group). Both were incubated in Krebs solution at $37^{\circ} \mathrm{C}$. One was set as the control without hypoxia. The other was subjected to 60 minutes of hypoxia followed by 30 minutes of reoxygenation. Concentration-contraction curves to $\mathrm{U}_{46619}(-10 \sim 6.5 \log \mathrm{M})$ were then established.

Effect of $H-R$ on EDHF-mediated relaxation. In these experiments, again, 2 rings from the same coronary microartery were allocated into 2 groups ( $\mathrm{n}=6$ in each group). Both were incubated in Krebs solution at $37^{\circ} \mathrm{C}$. One was set as the control without hypoxia. The other was subjected to 60 minutes of hypoxia followed by 30 minutes of reoxygenation. The EDHF-mediated relaxation to bradykinin $(-10 \sim 6 \log \mathrm{M})$ was established in the $\mathrm{U}_{46619^{-}}$ precontraction.

The relaxation study is only reliable when the contraction is not significantly altered by a certain degree of H-R. The design for the above contractility study is to explore whether the contraction after 60 minutes of hypoxia and 30 minutes of reoxygenation is suitable to be used as the precontraction to test the effect of $\mathrm{H}-\mathrm{R}$ on relaxation.

Protocol IV. Effect of $\mathrm{IK}_{\mathrm{Ca}} / \mathrm{SK}_{\mathrm{Ca}}$ activator 1-EBIO on EDHF-mediated relaxation reduced by $\mathbf{H}-\mathbf{R}$. Two rings were allocated to 2 groups $(\mathrm{n}=6)$, incubated in Krebs solution and normalized at $37^{\circ} \mathrm{C}$. Both were subjected to 60 minutes of hypoxia followed by 30 minutes of reoxygenation. In the 2 groups, the H-R was induced in the myograph with or without addition of 1-EBIO $(600 \mu \mathrm{mol} / \mathrm{L})$. After H-R and washout, the EDHF-mediated concentration-relaxation curve was established in response to bradykinin $(-10 \sim 6 \log \mathrm{M})$ in the presence of ${ }_{\mathrm{L}}-\mathrm{NNA}$, Indo, and $\mathrm{HbO}$. 
Separate control experiments on the effect of the solvent of 1-EBIO (ethanol $30 \mu \mathrm{L})(\mathrm{n}=6)$ were performed that showed no effect of the solvent on the EDHF-mediated relaxation.

Protocol V. Effect of H-R on EDHF-mediated hyperpolarization and the effect of 1-EBIO-single cell membrane potential measurement. A ring of the coronary microartery was mounted in the myograph and normalized as described earlier. A conventional glass microelectrode was inserted into a single smooth muscle cell from the adventitial surface of the ring and the cellular membrane potential was measured.

Group A: Control group $(n=6)$. With the presence of $\mathrm{L}^{-\mathrm{NNA}}$, Indo, and $\mathrm{HbO}$, the resting membrane potential of the smooth muscle cell in the vessel was recorded. Bradykinin $(0.1 \mu \mathrm{mol} / \mathrm{L})$ was then added to induce hyperpolarization and the membrane potential was continuously measured.

Group B: Effect of H-R on the EDHF-mediated hyperpolarization $(n=6)$. After 60 minutes of hypoxia followed by 30 minutes of reoxygenation, with the presence of ${ }_{\mathrm{L}}$-NNA, Indo, and $\mathrm{HbO}$, the resting membrane potential and EDHF-mediated hyperpolarization induced by bradykinin in the smooth muscle cell were recorded.

Group C: Effect of 1-EBIO on the EDHF-mediated hyperpolarization in response to $H-R(n=6)$. In these experiments, during 60 minutes of hypoxia and 30 minutes of reoxygenation, 1-EBIO $(600 \mu \mathrm{mol} / \mathrm{L})$ was added into Krebs solution. In the presence of ${ }_{\mathrm{L}}-\mathrm{NNA}$, Indo, and $\mathrm{HbO}$, the resting membrane potential and EDHF-mediated hyperpolarization induced by bradykinin in the smooth muscle cell were recorded.

Protocol VI. Effect of 1-EBIO on EDHF-mediated relaxation in St Thomas' Hospital cardioplegic solution (ST solution) at different temperatures. Group A: At $37^{\circ} \mathrm{C}$ $(n=6)$. Two rings were allocated to 2 groups, both incubated in Krebs solution and normalized at $37^{\circ} \mathrm{C}$. The Krebs solution in the myograph chamber was then changed to ST solution. The rings were incubated in ST solution at $37^{\circ} \mathrm{C}$ and subjected to hypoxia for 60 minutes followed by 30 minutes of reoxygenation with or without the presence of 1-EBIO $(600 \mu \mathrm{mol} / \mathrm{L})$, respectively. After $\mathrm{H}-\mathrm{R}$, the EDHF-mediated relaxation curve to bradykinin $(-10 \sim 6$ $\log \mathrm{M}$ ) was established in the presence of ${ }_{\mathrm{L}}$-NNA, Indo, and $\mathrm{HbO}$.

Group B: At $4^{\circ} \mathrm{C}(n=6)$. The protocol of these experiments was similar to that in the group A except that during H-R in ST solution, the temperature was reduced to $4^{\circ} \mathrm{C}$. These experiments were designed owing to our previous findings that the effect of H-R and ST solution is temperature-dependent. ${ }^{12}$

\section{Statistical Analysis}

Data were expressed as mean \pm SEM and were analyzed with paired, unpaired $t$ test, or analysis of variance (1-way ANOVA) followed by the Scheffé $F$ test when appropriate.

\section{Chemicals}

Chemicals included the following: bradykinin, iberiotoxin, charybdotoxin, apamin, ${ }_{\mathrm{L}}$-NNA, Indo, $\mathrm{HbO}$ (Sigma); 1-EBIO (Tocris Cookson Ltd, Bristol, United Kingdom), and $\mathrm{U}_{46619}$ (Cayman Chemical, Ann Arbor, Mich). ST solution was purchased from David Bull Laboratories, Mulgrave, Victoria, Australia.

\section{RESULTS}

Protocol I. Effect of H-R on Endothelial $I K_{\mathrm{Ca}}$ and SK $_{\text {Ca }}$ Currents

Hypoxic exposure markedly reduced whole-cell $\mathrm{K}^{+}$current of endothelial cells $(26.0 \pm 1.1 \mathrm{pA} / \mathrm{pF}$ to $17.6 \pm$ $1.2 \mathrm{pA} / \mathrm{pF}$, at $100 \mathrm{mV}, P<.01, \mathrm{n}=4$ in each group in this protocol). $\mathrm{BK}_{\mathrm{Ca}}$ blocker iberiotoxin did not cause significant inhibition on endothelial $\mathrm{K}^{+}$current, whereas application of $\mathrm{IK}_{\mathrm{Ca}}$ blocker charybdotoxin markedly reduced the current with further inhibition observed with apamin, a $\mathrm{SK}_{\mathrm{Ca}}$ blocker. The current sensitive to charybdotoxin or apamin was more significant in the normoxic group than that in the hypoxic group. Charybdotoxin-sensitive current was reduced from $6.9 \pm 0.6 \mathrm{pA} / \mathrm{pF}$ to $2.8 \pm 0.6 \mathrm{pA} / \mathrm{pF}$ after hypoxic exposure and apamin-sensitive current $(4.3 \pm$ $0.4 \mathrm{pA} / \mathrm{pF})$ was decreased to $1.5 \pm 0.3 \mathrm{pA} / \mathrm{pF}(P<.01)$. The activation of 1-EBIO on $\mathrm{K}^{+}$current was blunted by hypoxic exposure $(30.6 \pm 1.5 \mathrm{vs} 44.0 \pm 2.8 \mathrm{pA} / \mathrm{pF}$ under normoxia, $P<.01)$; however, the inhibition of hypoxia on the basal $\mathrm{K}^{+}$current $(18.5 \pm 1.9$ vs $27.8 \pm 1.3 \mathrm{pA} / \mathrm{pF})$ was recovered by the application of 1-EBIO $(30.6 \pm 1.5 \mathrm{pA} / \mathrm{pF}$, $P>.05$ ) (Figure 1).

\section{Protocol II. Effect of H-R on Protein Expression of Endothelial $\mathrm{IK}_{\mathrm{Ca}}$ and the Effect of 1-EBIO}

The protein content of $\mathrm{IK}_{\mathrm{Ca}}$ in porcine coronary endothelial cells was markedly decreased after H-R exposure ( $\mathrm{n}=6$ in each group). Although pretreatment with the $\mathrm{IK}_{\mathrm{Ca}} / \mathrm{SK}_{\mathrm{Ca}}$ activator 1-EBIO during hypoxia may recover $\mathrm{K}^{+}$current in endothelial cells to the level seen under normoxic condition, as shown in Figure 1, $G$ to $I$, there was no alteration at the protein level of the endothelial $\mathrm{IK}_{\mathrm{Ca}}$ (Figure 2).

\section{Protocol III. Effect of H-R on Contractility and EDHF-Mediated Relaxation}

Resting force. There were no significant differences among the arteries incubated in Krebs, ST solution, or ST solution containing 1-EBIO, either at $37^{\circ} \mathrm{C}$ or at $4{ }^{\circ} \mathrm{C}$, regarding the resting force $(P>.05)$. 

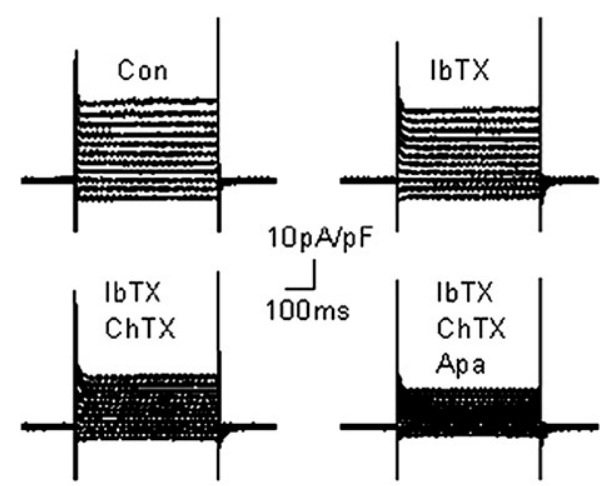

A
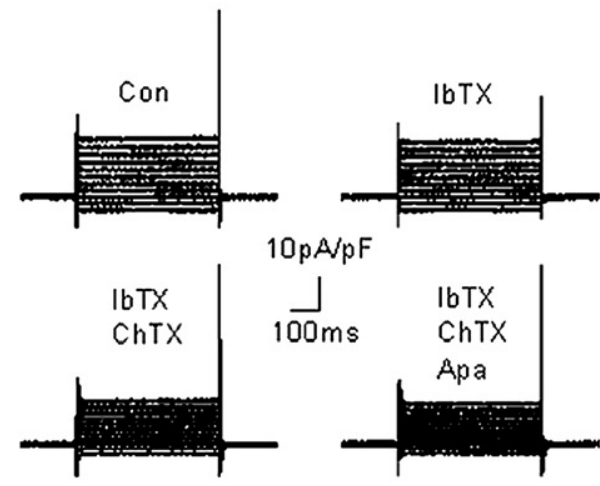

$10 \mathrm{pA} / \mathrm{pF}$

C

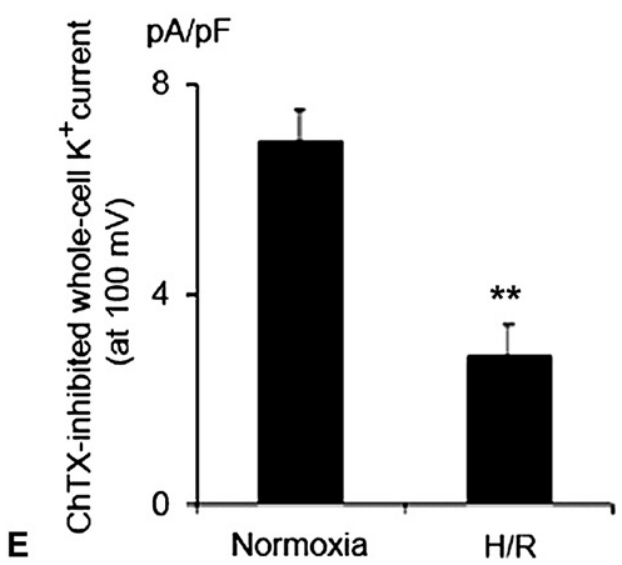

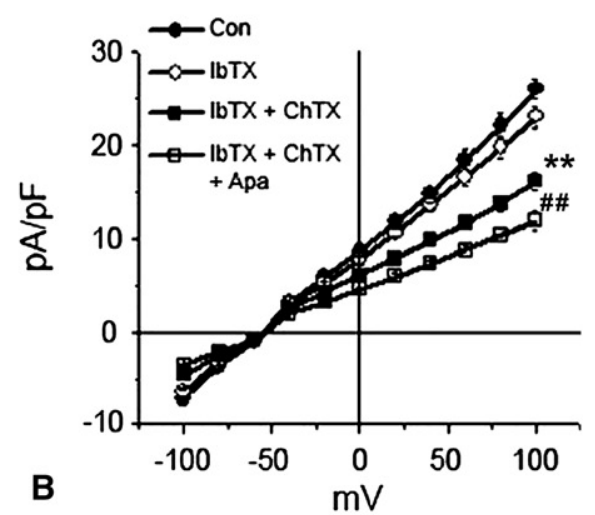
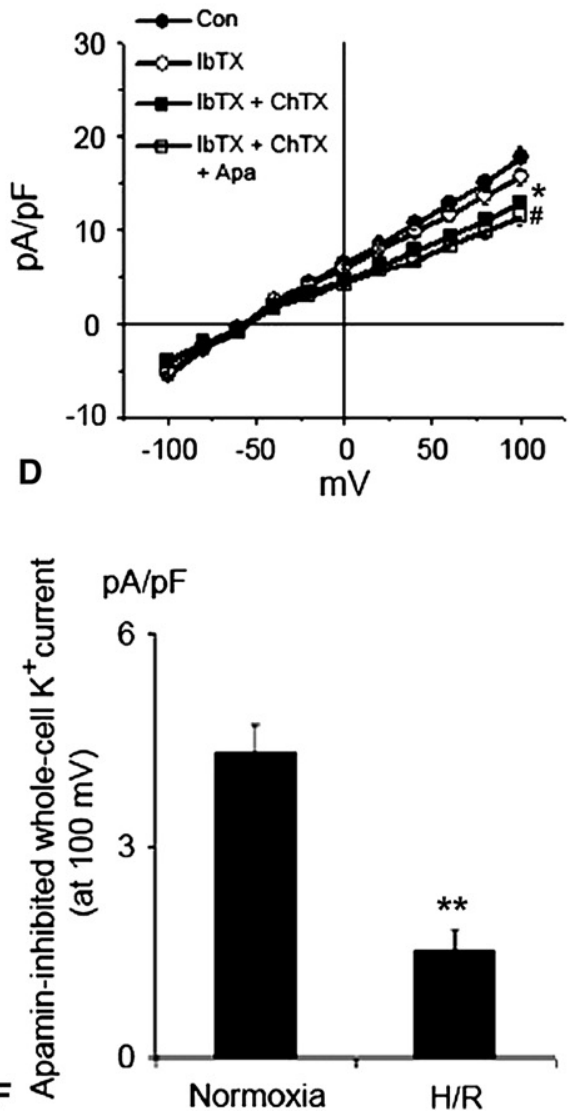

FIGURE 1. Representative traces (A) and current-voltage relationship of the whole-cell $\mathrm{K}^{+}$current of porcine coronary artery endothelial cells without (normoxia, A and B) or with the exposure to hypoxia-reoxygenation $(H / R)(\mathrm{C}$ and D). Currents were elicited by $20 \mathrm{mV}$ step pulses from -100 to $+100 \mathrm{mV}$ with a holding potential of $-60 \mathrm{mV}$. $\mathrm{BK}_{\mathrm{Ca}}$ blocker iberiotoxin $(I b T X ; 100 \mathrm{nmol} / \mathrm{L})$ did not significantly inhibit the current, whereas further application of $\mathrm{IK}_{\mathrm{Ca}}$ blocker charybdotoxin $(C h T X ; 100 \mathrm{nmol} / \mathrm{L})$ markedly reduced the current with further inhibition observed upon the application of $\mathrm{SK}_{\mathrm{Ca}}$ blocker apamin (Apa; $100 \mathrm{nmol} / \mathrm{L}) .{ }^{* *} P<.001,{ }^{*} P<.05$ versus control; ${ }^{\# \#} P<.01,{ }^{\#} P<.05$ versus IbTX and ChTX. Hypoxia reduced ChTX-sensitive (E) and apaminsensitive $\mathrm{K}^{+}$current $(\mathrm{F})(\mathrm{n}=4)$. ${ }^{* *} P<.01$ versus normoxia. Activation of the whole-cell $\mathrm{K}^{+}$current by $\mathrm{IK}_{\mathrm{Ca}} / \mathrm{SK} \mathrm{Ca}$ activator 1 -EBIO $(600 \mu \mathrm{mol} / \mathrm{L})(\mathrm{G}, \mathrm{nor}-$ moxia) was blunted by hypoxic exposure $(\mathrm{H})$; however, the inhibition of hypoxia on basal $\mathrm{K}^{+}$current was recovered by the application of 1 -EBIO (I) $(\mathrm{n}=4)$. ${ }^{* *} P<.01$ versus control $(C o n),{ }^{\# \#} P<.01$ versus control or 1 -EBIO in normoxia group. $P>.05,1$-EBIO in hypoxia versus control in normoxia. 

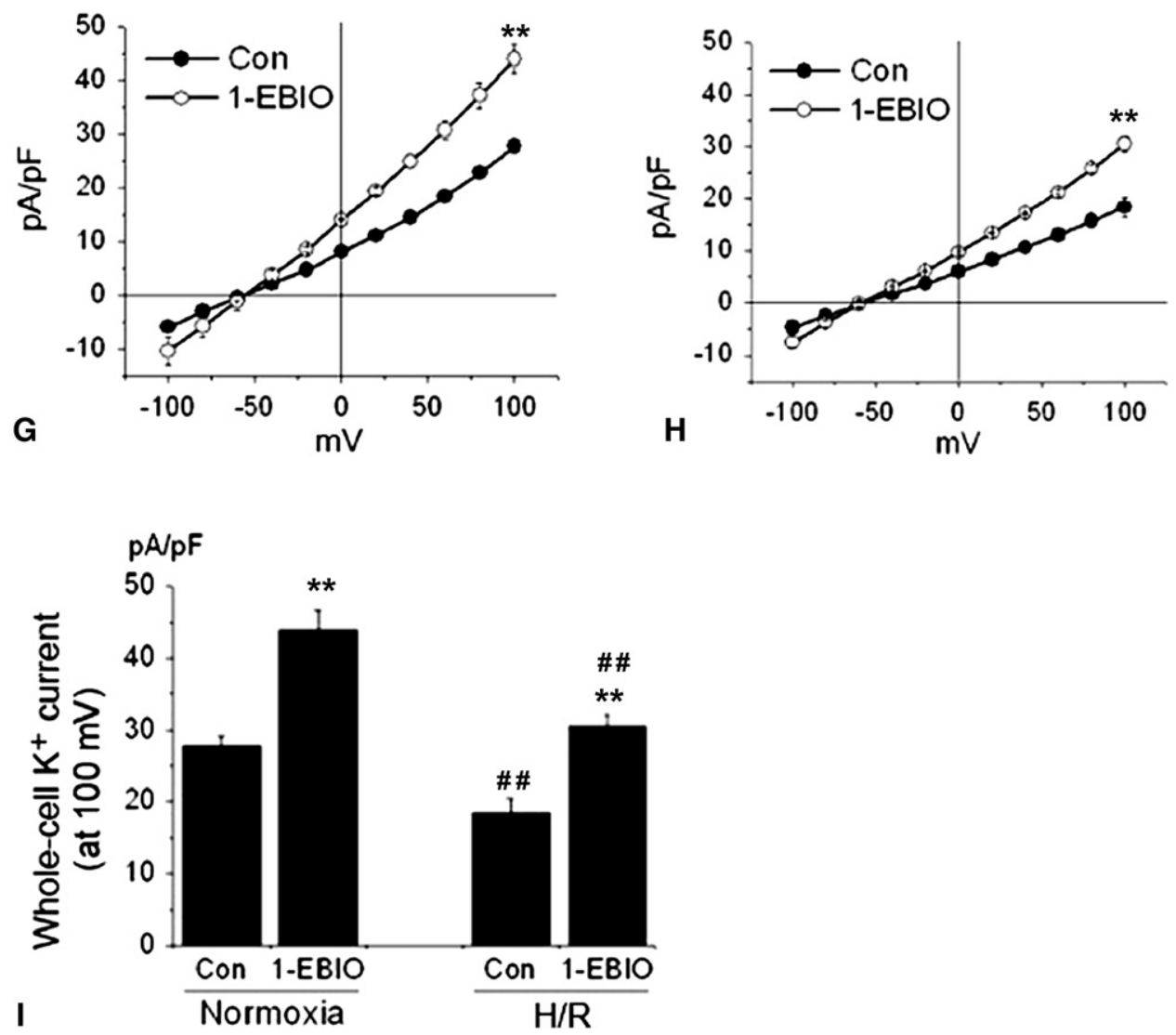

FIGURE 1. (continued).

Effect of H-R on contractility. Hypoxia for 60 minutes, followed by 30 minutes of reoxygenation, did not significantly alter the contraction to $\mathrm{U}_{46619}$ (Figure 3, A) but significantly reduced the EDHF-mediated relaxation (Figure 3,B). These results indicate that contraction is more tolerant to $\mathrm{H}-\mathrm{R}$ than the endothelium-dependent relaxation (EDHF-mediated). Therefore, the EDHF-mediated relaxation in response to 60 minutes of hypoxia and 30 minutes of reoxygenation was able to be tested in this project.

Effect of H-R on EDHF-mediated relaxation. Exposure to hypoxia for 60 minutes in Krebs solution at $37^{\circ} \mathrm{C}$ followed by 30 minutes of reoxygenation significantly decreased bradykinin-induced, EDHF-mediated relaxation from $82.3 \% \pm 2.9 \%$ to $43.3 \% \pm 6.3 \%(P<.001,95 \%$ confidence interval [CI]: $29.0 \%-47.7 \%$ ) with unchanged $\mathrm{EC}_{50}$ (effective concentration to induce $50 \%$ of the maximum effect) $(-7.60 \pm 0.08$ vs $-7.73 \pm 0.83 \log \mathrm{M}$ in the control group, $P=.29,95 \%$ CI: -0.13 to $0.39 \log$; Figure $3, B$ ).

\section{Protocol IV. Effect of $\mathrm{IK}_{\mathrm{Ca}} / \mathrm{SK}_{\mathrm{Ca}}$ Activator 1-EBIO on EDHF-Mediated Relaxation Reduced by H-R}

Addition of 1-EBIO to Krebs solution during 60 minutes of hypoxia and 30 minutes of reoxygenation restored the
EDHF-mediated relaxation $(90.7 \% \pm 3.6 \%$, compared with $43.4 \% \pm 5.8 \%$ without 1 -EBIO, $P<.001,95 \%$ CI: $30.8 \%-61.8 \%$; Figure $3, C$ ). With regard to $\mathrm{EC}_{50}$, no significant change was observed $(-7.76 \pm 0.11$ vs $-7.60 \pm 0.08$ $\log \mathrm{M}, P=.26,95 \% \mathrm{CI}:-0.14$ to $0.46 \log \mathrm{M})$.

\section{Protocol V. Effect of H-R on EDHF-Mediated}

Hyperpolarization and the Effect of 1-EBIO-Single Cell Membrane Potential Measurement

Exposure to H-R with or without 1-EBIO did not alter the resting membrane potential of the porcine coronary smooth muscle cell (control: $-57.2 \pm 1.0 \mathrm{mV}$; H-R: $-57.4 \pm 1.6 \mathrm{mV}$; H-R+1-EBIO: $-59.6 \pm 0.5 \mathrm{mV}, P=.285$ between groups, $P=$.99: control vs H-R; $P=.36$ : control vs H-R $+1-$ EBIO; $P=.41:$ H-R vs H-R+1-EBIO, 1-way ANOVA, Figure $4, A$ ). However, H-R significantly decreased the amplitude of the EDHF-mediated hyperpolarization to bradykinin from $8.6 \pm 0.5 \mathrm{mV}$ to $6.0 \pm 0.3 \mathrm{mV}(P=.003$, 1-way ANOVA, Figure $4, B)$. Addition of 1-EBIO significantly recovered the hyperpolarization $(7.8 \pm 0.4 \mathrm{mV}, P=.47$ vs control, $P=.028$ vs H-R, 1-way ANOVA, Figure $4, B$ ). Figure $4, C$, gives examples of original traces of the cellular membrane potential. 


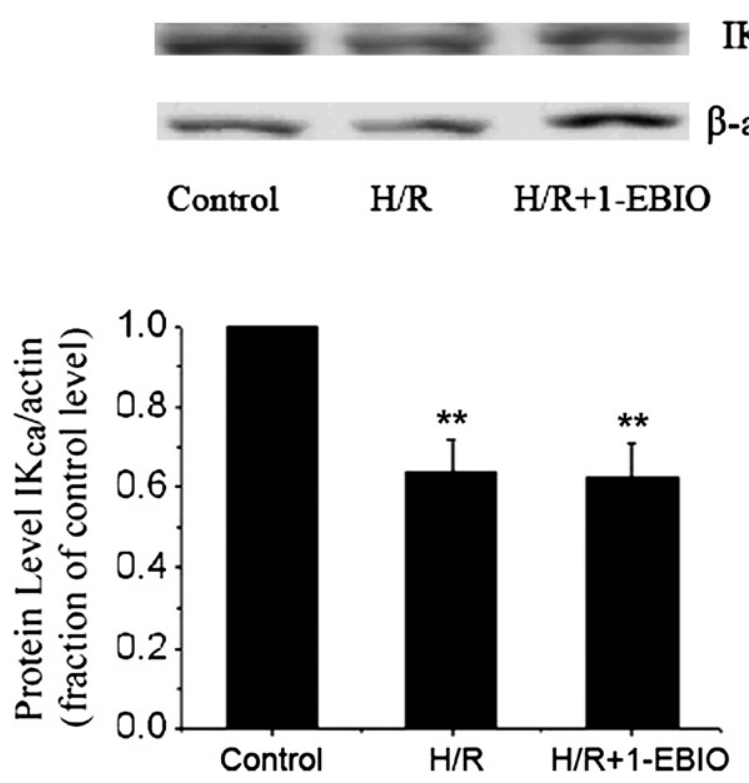

FIGURE 2. IK $\mathrm{Ca}$ protein expression in porcine coronary endothelial cells exposed to 1 hour of normoxia (control), 1 hour of hypoxia $(H / R)$, or 1 hour of hypoxia with the presence of 1-EBIO $(H / R+1-E B I O)$, followed by reoxygenation. Bar graphs show $\mathrm{IK}_{\mathrm{Ca}}$ protein expression normalized to $\beta$-actin (mean $\pm \mathrm{SEM} ; \mathrm{n}=6$; ${ }^{* *} P<.01$ vs control). $I K_{C a}$, Intermediate conductance calcium-activated $\mathrm{K}^{+}$channels.

\section{Protocol VI. Effect of 1-EBIO on EDHF-Mediated Relaxation in ST Solution at Different Temperatures}

Addition of 1-EBIO in ST solution significantly increased the EDHF-mediated relaxation reduced by $\mathrm{H}-\mathrm{R}$ in this solution (at $37^{\circ} \mathrm{C}: 82.6 \% \pm 2.6 \%$ vs $28.9 \% \pm 1.8 \%, P<.001$, 95\% CI: $46.6 \%-60.7 \%$, Figure 5, $A$; at $4{ }^{\circ} \mathrm{C}: 84.3 \% \pm$ $5.0 \%$ vs $43.1 \% \pm 2.6 \%, P<.001, \quad 95 \% \quad$ CI: $28.7 \%-53.6 \%$, Figure $5, B$ ). Again, the change of $\mathrm{EC}_{50}$ did not reach statistical significance $(-7.69 \pm 0.11$ vs $-8.07 \pm 0.18 \log \mathrm{M}$ at $37^{\circ} \mathrm{C}, P=.11,95 \% \mathrm{CI}:-0.10$ to $0.85 \log \mathrm{M}$ and $-7.46 \pm 0.08$ vs $-7.60 \pm 0.09 \log \mathrm{M}$, $P=.27,95 \% \mathrm{CI}:-0.13$ to $0.41 \log \mathrm{M}$ at $4^{\circ} \mathrm{C}$ ).

\section{DISCUSSION}

The present study for the first time demonstrated that in porcine coronary arteries, (1) hypoxic exposure markedly reduced endothelial $\mathrm{IK}_{\mathrm{Ca}}$ and $\mathrm{SK}_{\mathrm{Ca}}$ currents and protein content of $\mathrm{IK}_{\mathrm{Ca}}$ with corresponding changes of EDHF-mediated function; (2) the activator of $\mathrm{IK}_{\mathrm{Ca}} / \mathrm{SK}_{\mathrm{Ca}} 1$-EBIO may prevent the reduction of the EDHF-mediated hyperpolarization and associated relaxation caused by H-R and such effects are in accordance with the enhancement of $\mathrm{K}^{+}$currents in the endothelial cells; (3) the protective effect of 1-EBIO also exists when added in cardioplegic solutions. Therefore, addition of the activator of $\mathrm{IK}_{\mathrm{Ca}} / \mathrm{SK}_{\mathrm{Ca}}$ in cardioplegic solutions during the H-R period may become a new strategy of protection of coronary endothelium in cardiac surgery.
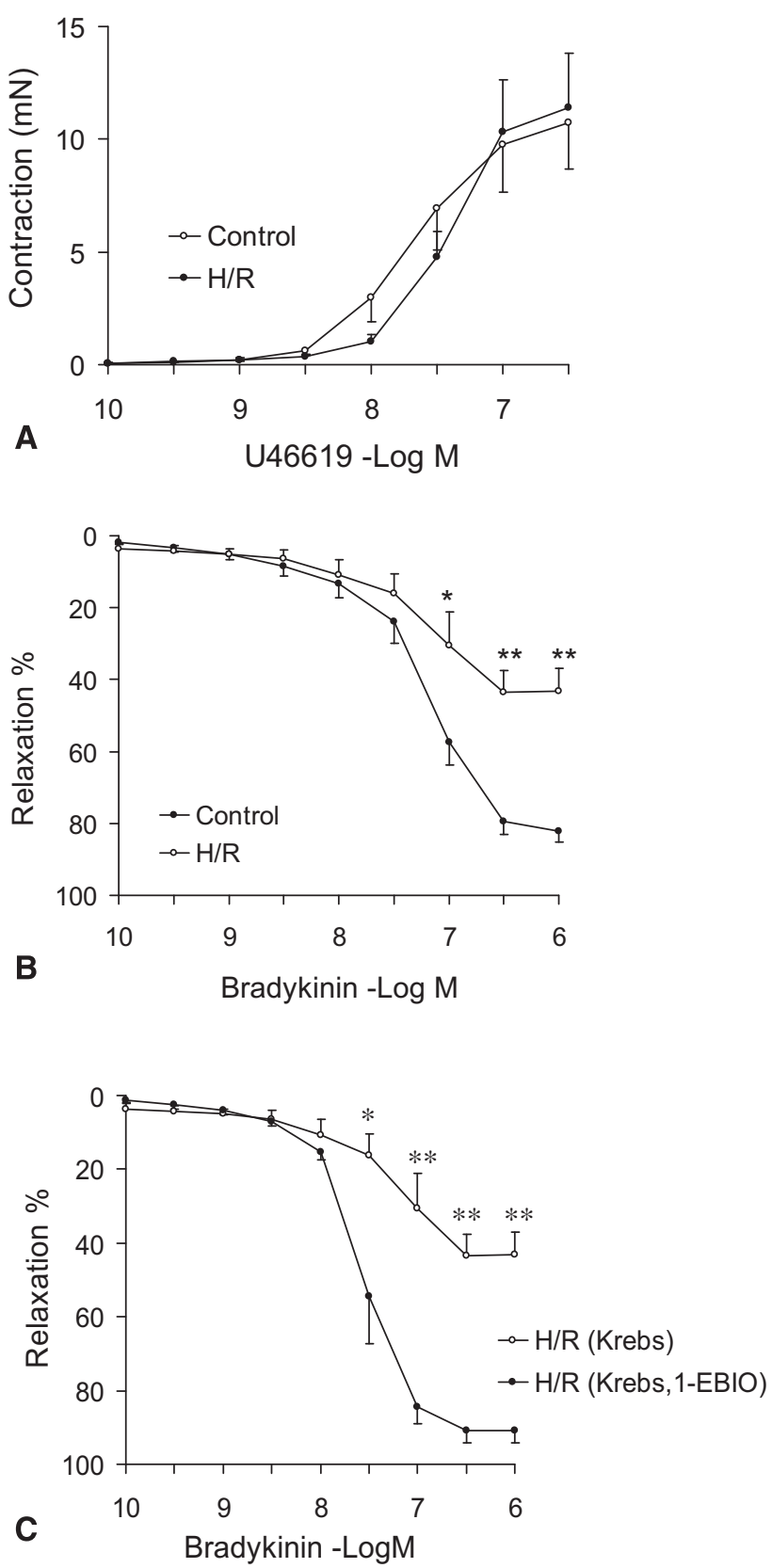

FIGURE 3. Effect of hypoxia (60 minutes) and reoxygenation (30 minutes) at $37^{\circ} \mathrm{C}(H / R)$ on the contraction and EDHF-mediated relaxation in porcine coronary microarteries ( $\mathrm{n}=6$ in each group). A, Concentrationcontraction curves to $\mathrm{U}_{46619}$. B, EDHF-mediated relaxation to bradykinin in $\mathrm{U}_{46619}(10 \mathrm{nmol} / \mathrm{L})$-induced precontraction in the presence of indometh$\operatorname{acin}(7 \mu \mathrm{mol} / \mathrm{L}), \mathrm{N}^{\mathrm{G}}$-nitro-L-arginine $(300 \mu \mathrm{mol} / \mathrm{L})$, and oxyhemoglobin $(20$ $\mu \mathrm{mol} / \mathrm{L})$. Data are shown as mean \pm SEM. $* P<.05 ; * * P<.001$ compared with control group (unpaired $t$ test). C, EDHF-mediated concentrationrelaxation curves to bradykinin in $\mathrm{U}_{46619}(10 \mathrm{nmol} / \mathrm{L})$-precontracted microarteries in the presence of indomethacin $(7 \mu \mathrm{mol} / \mathrm{L}), \mathrm{N}^{\mathrm{G}}$-nitro-L-arginine (300 $\mu \mathrm{mol} / \mathrm{L})$, and oxyhemoglobin $(20 \mu \mathrm{mol} / \mathrm{L})$ after hypoxia (60 minutes)-reoxygenation (30 minutes) at $37^{\circ} \mathrm{C}$ in physiologic (Krebs) solution with (H/R 1-EBIO) or without (H/R) addition of 1-EBIO $(600 \mu \mathrm{mol} / \mathrm{L}) \mathrm{dur}-$ ing the $\mathrm{H} / \mathrm{R}$ period. $* P<.05 ; * * P<.001$, unpaired $t$ test $(\mathrm{n}=6$ in each group). $E D H F$, Endothelium-derived hyperpolarizing factor. 


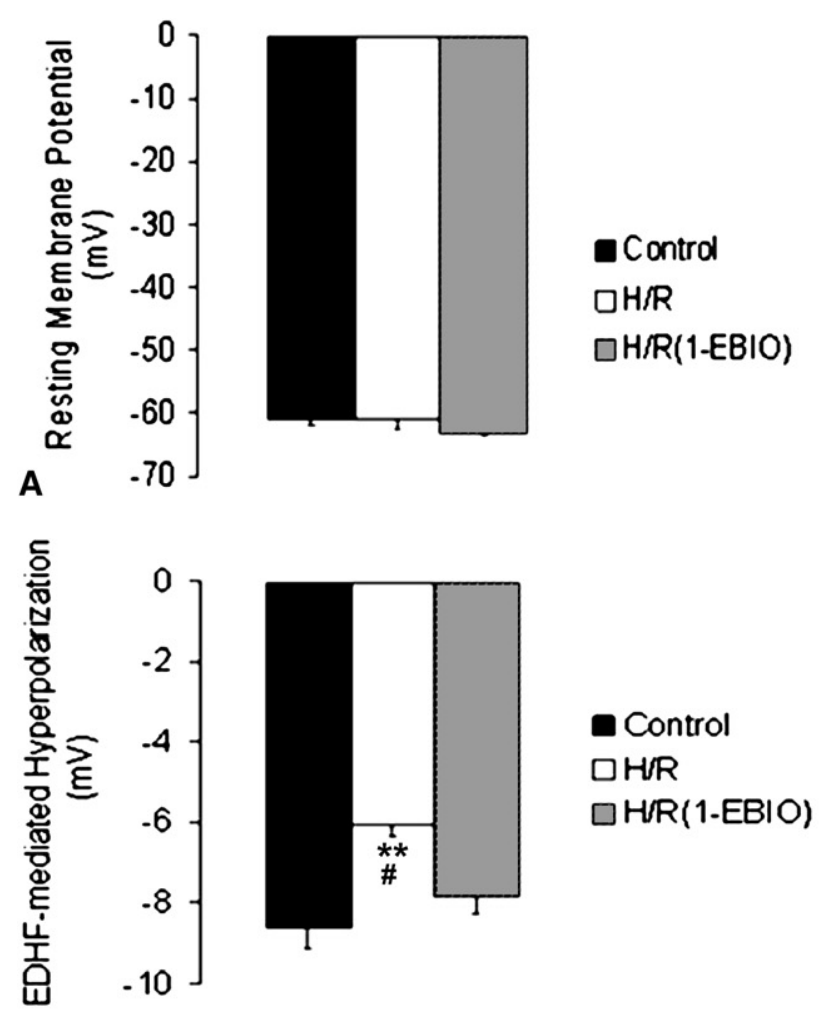

B

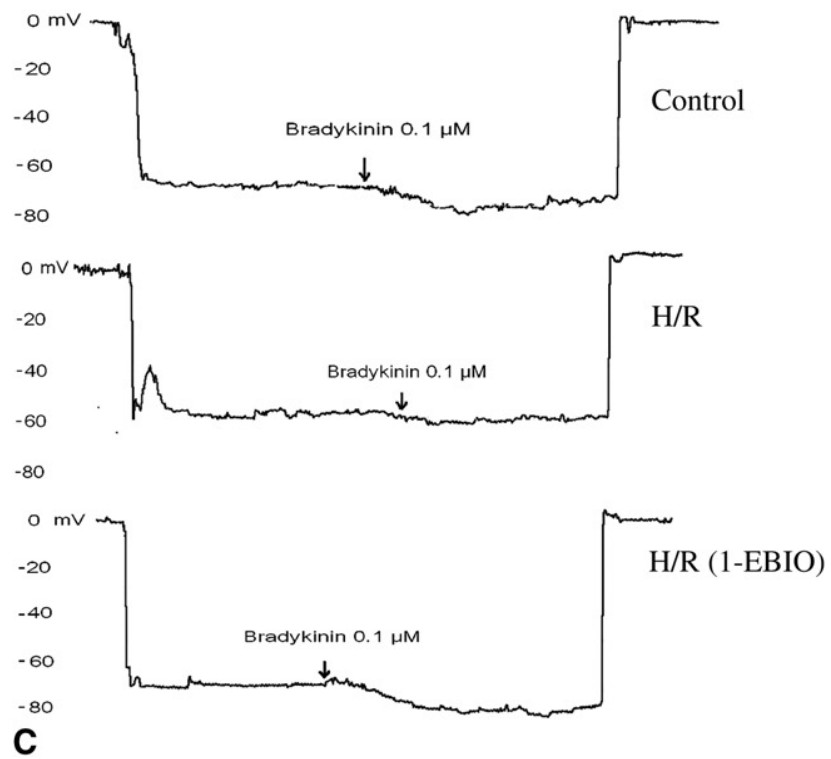

FIGURE 4. Membrane potential measurement ( $n=6$ in each group). A, The resting membrane potential of smooth muscle cells of the porcine coronary microartery under normalized condition without (control) or with hypoxia (60 minutes)-reoxygenation (30 minutes) at $37^{\circ} \mathrm{C}(\mathrm{H} / \mathrm{R})$ or with 1-EBIO $(600 \mu \mathrm{mol} / \mathrm{L})$ during H/R (H/R[1-EBIO]). B, EDHF-mediated hyperpolarization of a single smooth muscle cell of the coronary microartery to bradykinin $(0.1 \mu \mathrm{mol} / \mathrm{L})$ in the presence of indomethacin $(7 \mu \mathrm{mol} / \mathrm{L})$, $\mathrm{N}^{\mathrm{G}}$-nitro-L-arginine $(300 \mu \mathrm{mol} / \mathrm{L})$, and oxyhemoglobin $(20 \mu \mathrm{mol} / \mathrm{L})$. Data are shown as mean \pm SEM. ${ }^{* *} P<.01, \mathrm{H} / \mathrm{R}$ versus control; ${ }^{\#} P<.05, \mathrm{H} / \mathrm{R}$ versus $\mathrm{H} / \mathrm{R}$ (1-EBIO). No difference was observed between
The role of $\mathrm{IK}_{\mathrm{Ca}} / \mathrm{SK}_{\mathrm{Ca}}$ channels on endothelial cells and vasculature was well defined by others ${ }^{16,17,23,30}$ by using multiple approaches such as patch-clamp, Western blotting, immunohistochemistry, and gene expression. On the other hand, the role and precise mechanisms of the endothelial $\mathrm{IK}_{\mathrm{Ca}} / \mathrm{SK}_{\mathrm{Ca}}$ and the activators of these channels on vascular protection during ischemia/reperfusion are unclear at the ion channel level. We therefore designed the present study by using patch-clamp, molecular methods, as well as functional investigations to reveal the mechanism.

\section{Hypoxic Exposure and $\mathrm{K}^{+}$Current of Endothelial Cells}

We have demonstrated that hypoxia markedly reduced whole-cell $\mathrm{K}^{+}$current of endothelial cells and the reduction mainly involves reduced currents of $\mathrm{IK}_{\mathrm{Ca}}$ and $\mathrm{SK}_{\mathrm{Ca}}$. These changes are coupled with the decreased protein level of $\mathrm{IK}_{\mathrm{Ca}}$. Owing to the fact that $\mathrm{SK}_{\mathrm{Ca}}$ has multiple subtypes (SK1-3), we did not intend to identify the protein changes of the subtypes of $\mathrm{SK}_{\mathrm{Ca}}$. Further, these changes are in accordance with the functional test that showed reduced EDHF-mediated relaxation, a widely known function of the endothelial $\mathrm{IK}_{\mathrm{Ca}}$ and $\mathrm{SK}_{\mathrm{Ca}}$.

\section{Activator of $\mathrm{IK}_{\mathrm{Ca}}$ and $\mathrm{SK}_{\mathrm{Ca}}$ and Endothelium}

$\mathrm{K}^{+}$channels have particular importance in the endothelium-smooth muscle interaction. First, a number of subtypes of $\mathrm{K}^{+}$channels such as $\mathrm{BK}_{\mathrm{Ca}}{ }^{8}$ and $\mathrm{Kir}$ as well as $\mathrm{Na}^{+} / \mathrm{K}^{+}$ exchange pump ${ }^{7}$ located at the smooth muscle plasma membrane are responsible for the smooth muscle hyperpolarization/relaxation in the EDHF pathway (Figure E1). Furthermore, endothelial $\mathrm{IK}_{\mathrm{Ca}}$ and $\mathrm{SK}_{\mathrm{Ca}}$ are highly homologous channels. Recent studies recruited $\mathrm{IK}_{\mathrm{Ca}}$ as a member of $\mathrm{SK}_{\mathrm{Ca}}$ family and referred to it as SK4 owing to its high degree of similarity with the other $\mathrm{SK}_{\mathrm{Ca}}(\mathrm{SK} 1-\mathrm{SK} 3){ }^{34}$

Activators of $\mathrm{IK}_{\mathrm{Ca}}$ often activate $\mathrm{SK}_{\mathrm{Ca}}$ as well. 1-EBIO represents the first characterized pharmacologic opener of $\mathrm{IK}_{\mathrm{Ca}}{ }^{35}$ that also opens $\mathrm{SK}_{\mathrm{Ca}}{ }^{36}$ The role of $\mathrm{IK}_{\mathrm{Ca}}$ and $\mathrm{SK}_{\mathrm{Ca}}$ in the EDHF pathway is probably related to the release of EDHF from the endothelial cell. The known EDHFs such as $\mathrm{K}^{+}$are released from the endothelial cell with activation of $\mathrm{IK}_{\mathrm{Ca}}$ and $\mathrm{SK}_{\mathrm{Ca}}$. Therefore, we hypothesized that previous findings that the EDHF-mediated relaxation is reduced owing to H-R may be related to the alteration of the activity of the endothelial $\mathrm{IK}_{\mathrm{Ca}}$ and $\mathrm{SK}_{\mathrm{Ca}}$.

control group and H/R (1-EBIO) group ( $P=.47,1$-way ANOVA followed by Scheffé $\mathrm{F}$ test). C, Original tracings of EDHF-mediated hyperpolarization induced by bradykinin. The arteries were under normalized condition without (control) or with hypoxia (60 minutes)-reoxygenation (30 minutes) at $37^{\circ} \mathrm{C}(\mathrm{H} / \mathrm{R})$ or with 1 -EBIO $(600 \mu \mathrm{mol} / \mathrm{L})$ during $\mathrm{H} / \mathrm{R}(\mathrm{H} / \mathrm{R}[1-\mathrm{EBIO}])$. $E D H F$, Endothelium-derived hyperpolarizing factor; 1-EBIO, 1-ethyl2-benzimidazolinone. 


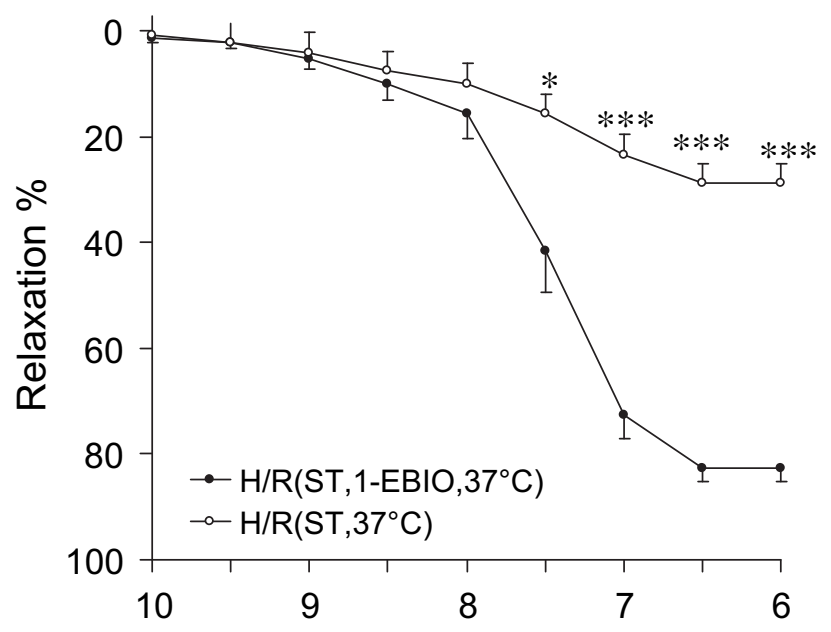

A

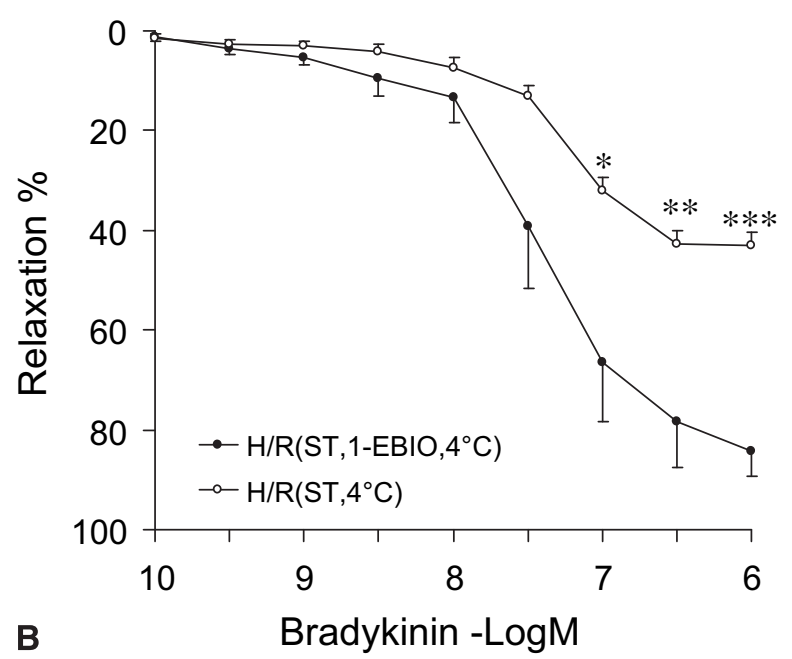

FIGURE 5. EDHF-mediated concentration-relaxation curves to bradykinin in $\mathrm{U}_{46619}(10 \mathrm{nmol} / \mathrm{L})$-precontracted microarteries in the presence of indomethacin $(7 \mu \mathrm{mol} / \mathrm{L}), \mathrm{N}^{\mathrm{G}}$-nitro-L-arginine $(300 \mu \mathrm{mol} / \mathrm{L})$, and oxyhemoglobin $(20 \mu \mathrm{mol} / \mathrm{L})$ after hypoxia (60 minutes)-reoxygenation (30 minutes) at $37^{\circ} \mathrm{C}(\mathrm{A})$ or $4^{\circ} \mathrm{C}(\mathrm{B})$ in St Thomas' Hospital cardioplegic (ST) solution with (H/R[ST,1-EBIO]) or without (H/R[ST]) addition of 1-EBIO $(600 \mu \mathrm{mol} / \mathrm{L})$ during the $\mathrm{H} / \mathrm{R}$ period. Data are shown as mean $\pm \mathrm{SEM}$. $* P<.05, * * P<.01, * * * P<.001$, unpaired $t$ test ( $\mathrm{n}=6$ in each group).

In the present study, we used multiple methods to determine the mechanism underlying the reduction of the EDHF-mediated relaxation. We conducted the present study by directly measuring the single cell membrane potential in association with relaxation studies under the condition that the production of $\mathrm{NO}$ and $\mathrm{PGI}_{2}$ were abolished. ${ }^{33}$ We are therefore confident that the findings in the present study regarding hyperpolarization and relaxation are truly related to EDHF - the "non-NO-non-PGI ${ }_{2}$ " pathway. Importantly, the role of $\mathrm{IK}_{\mathrm{Ca}}$ and $\mathrm{SK}_{\mathrm{Ca}}$ in this EDHF-mediated function has been repeatedly demonstrated in our previous studies in porcine coronary arteries ${ }^{33,37}$ as well as by others, ${ }^{38}$ indicated by the potent inhibition of the specific inhibitors of these channels-charybdotoxin and apamin.

\section{The Effect of 1-EBIO in Physiologic and Cardioplegic Solution}

In the present study, we demonstrated that addition of 1-EBIO may be favorable to the regulation of EDHF pathway by maintaining the hyperpolarization in response to bradykinin. This effect exists not only in physiologic solution but also in ST solution. ST solution contains $20 \mathrm{mmol} / \mathrm{L} \mathrm{K}^{+}$ that has been demonstrated to impair the EDHF-mediated function. ${ }^{24-27}$ The hyperkalemia-induced inhibition of $\mathrm{K}^{+}$ channels is possibly decreased by addition of $\mathrm{K}^{+}$channel openers. Use of activators of $\mathrm{IK}_{\mathrm{Ca}}$ and $\mathrm{SK}_{\mathrm{Ca}}$ is a new concept, based on the fact that these two $\mathrm{K}^{+}$channels are directly related to the mechanism of EDHF in the endothelial cell, as mentioned earlier.

The present study was a continuous investigation to our previous preliminary work. ${ }^{28}$ Owing to the difficulties in the patch-clamp technique in the single porcine coronary endothelial cell, we have not been able to complete this study until recently.

\section{Effect of Temperature}

The present study also showed that the protective effect of the activator of $\mathrm{IK}_{\mathrm{Ca}}$ and $\mathrm{SK}_{\mathrm{Ca}}$ exists under both normothermia and hypothermia. This is particularly important in cardiac surgery when hypothermic cardioplegia is used to protect the heart.

\section{Clinical Implications}

I-R/H-R injury is the major cause of mortality and morbidity in cardiac surgery, including heart transplantation. Coronary endothelial protection is an important aspect in myocardial protection. $^{21-28,39}$ In past decades, several strategies have been developed to protect endothelium from I-R/H-R injury. ${ }^{13}$ The present study specifically targets on the $\mathrm{IK}_{\mathrm{Ca}}$ and $\mathrm{SK}_{\mathrm{Ca}}$ channels of the endothelial cell and demonstrates the favorable effect of $\mathrm{IK}_{\mathrm{Ca}} / \mathrm{SK}_{\mathrm{Ca}}$ activators in the preservation of endothelial function during H-R. This study provides evidence for a new strategy in the myocardial protection during cardiac surgery or in ischemic heart disease.

\section{Limitation of Study}

Although the clinical implications are clear, the present study is an in vitro investigation in coronary arteries at the level of single cell electrophysiology and vascular relaxation; to form a clinical protocol, more studies are warranted.

In conclusion, the present study demonstrated that in porcine coronary arteries, hypoxia markedly reduced endothelial $\mathrm{K}^{+}$currents related to $\mathrm{IK}_{\mathrm{Ca}}$ and $\mathrm{SK}_{\mathrm{Ca}}$ with downregulation of protein expression and EDHF-mediated relaxation. We also demonstrated that addition of the activator 
of $\mathrm{IK}_{\mathrm{Ca}} / \mathrm{SK}_{\mathrm{Ca}}$ in cardioplegic solutions during H-R period may become a new strategy of protection of coronary endothelium in cardiac surgery.

\section{References}

1. Ignarro LJ, Buga GM, Wood KS, Byrns RE, Chaudhuri G. Endothelium-derived relaxing factor produced and released from artery and vein is nitric oxide. Proc Natl Acad Sci U S A. 1987;84:9265-9.

2. Palmer RMJ, Ferrige AG, Moncada S. Nitric oxide release accounts for the biological activity of endothelium-derived relaxing factor. Nature. 1987;27:524-6.

3. Moncada S, Gryglewski R, Bunting S, Vane JR. An enzyme isolated from arteries transforms prostaglandin endoperoxides to an unstable substance that inhibits platelet aggregation. Nature. 1976;263:663-5.

4. Félétou M, Vanhoutte PM. Endothelium-derived hyperpolarizing factor: where are we now? Arterioscler Thromb Vasc Biol. 2006;26:1215-25.

5. Eichler I, Wibawa J, Grgic I, Knorr A, Brakemeier S, Pries AR, et al. Selective blockade of endothelial $\mathrm{Ca}^{2+}$-activated small- and intermediate-conductance $\mathrm{K}^{+}$-channels suppresses EDHF-mediated vasodilation. Br J Pharmacol. 2003; 138:594-601.

6. Félétou M, Vanhoutte PM, Weston AH, Edwards G. EDHF and endothelial potassium channels: IKCa and SKCa. Br J Pharmacol. 2003;140:225. author reply 2003;140:226.

7. Edwards G, Dora KA, Gardener MJ, Garland CJ, Weston AH. $\mathrm{K}^{+}$is an endothelium-derived hyperpolarizing factor in rat arteries. Nature. 1998;396: 269-72.

8. Li PL, Campbell WB. Epoxyeicosatrienoic acids activate $\mathrm{K}^{+}$channels in coronary smooth muscle through a guanine nucleotide binding protein. Circ Res. 1997;80: 877-84.

9. Doughty JM, Plane F, Langton PD. Charybdotoxin and apamin block EDHF in rat mesenteric artery if selectively applied to the endothelium. Am J Physiol. 1999; 276:H1107-12.

10. Hashimoto K, Pearson PJ, Schaff HV, Cartier R. Endothelial cell dysfunction after ischemic arrest and reperfusion: a possible mechanism of myocardial injury during reflow. J Thorac Cardiovasc Surg. 1991;102:688-94.

11. Ren Z, Yang Q, Floten HS, He GW. Hypoxic preconditioning in coronary microarteries: role of EDHF and $\mathrm{K}^{+}$channel openers. Ann Thorac Surg. 2002; 74:143-8.

12. Dong YY, Wu M, Yim AP, He GW. Hypoxia-reoxygenation, St. Thomas cardioplegic solution, and nicorandil on endothelium-derived hyperpolarizing factor in coronary microarteries. Ann Thorac Surg. 2005;80:1803-11.

13. Yang Q, He GW. Effect of cardioplegic and organ preservation solutions and their components on coronary endothelium-derived relaxing factors. Ann Thorac Surg. 2005;80:757-67.

14. Zweier JL, Talukder MA. The role of oxidants and free radicals in reperfusion injury. Cardiovasc Res. 2006;70:181-90.

15. Cao CM, Xia Q, Gao Q, Chen M, Wong TM. Calcium-activated potassium channel triggers cardioprotection of ischemic preconditioning.J Pharmacol Exp Ther. 2005;312:644-50.

16. Miura H, Wachtel RE, Liu Y, Loberiza FR Jr, Saito T, Miura M, et al. Flowinduced dilation of human coronary arterioles: important role of $\mathrm{Ca}(2+)$-activated $\mathrm{K}(+)$ channels. Circulation. 2001;103:1992-8.

17. Liu Y, Terata K, Chai Q, Li H, Kleinman LH, Gutterman DD. Peroxynitrite inhibits $\mathrm{Ca} 2+$-activated $\mathrm{K}+$ channel activity in smooth muscle of human coronary arterioles. Circ Res. 2002;91:1070-6.

18. Han JG, Yang Q, Yao XQ, Kwan YW, Shen B, He GW. Role of large conductance calcium-activated potassium channels of coronary arteries in heart preservation. J Heart Lung Transplant. 2009;28:1094-101.

19. Amark K, Berggren H, Björk K, Ekroth A, Ekroth R, Nilsson K, et al. Blood cardioplegia provides superior protection in infant cardiac surgery. Ann Thorac Surg. 2005;80:989-94.
20. Allen BS, Buckberg GD. Myocardial management in arterial revascularization. In: He GW, ed. Arterial grafting for coronary artery bypasses surgery. 2nd ed. Berlin, Heidelberg, New York: Springer-Verlag; 2006:51-62.

21. Faggian G, Forni A, Mazzucco A. Donor organ preservation in high-risk cardiac transplantation. Transplant Proc. 2004;36:617-9.

22. Sellke FW, Shafique T, Schoen FJ, Weintraub RM. Impaired endotheliumdependent coronary microvascular relaxation after cold potassium cardioplegia and reperfusion. J Thorac Cardiovasc Surg. 1993;105:52-8.

23. Feng J, Liu Y, Clements RT, Sodha NR, Khabbaz KR, Senthilnathan V, et al. Calcium-activated potassium channels contribute to human coronary microvascular dysfunction after cardioplegic arrest. Circulation. 2008;118(14 Suppl):S46-51.

24. Ge ZD, He GW. Altered endothelium-derived hyperpolarizing factor-mediated endothelial function in coronary microarteries by St Thomas' Hospital solution. J Thorac Cardiovasc Surg. 1999;118:173-80.

25. He GW, Yang CQ, Graier WF, Yang JA. Hyperkalemia alters EDHF-mediated hyperpolarization and relaxation in porcine coronary arteries. Am J Physiol. 1996;271:H760-7.

26. He GW. Hyperkalemia exposure impairs EDHF-mediated endothelial function in the human coronary artery. Ann Thorac Surg. 1997;63:84-7.

27. Yang Q, Zhang RZ, Yim AP, He GW. Release of nitric oxide and endotheliumderived hyperpolarizing factor (EDHF) in porcine coronary arteries exposed to hyperkalemia: effect of nicorandil. Ann Thorac Surg. 2005;79:2065-71.

28. Yang Q, Dong YY, Wu M, Yim AP, He GW. New strategy to protect coronary endothelium from ischemia-reperfusion injury in cardiac surgery by using $\mathrm{Ca}^{2+}$-activated $\mathrm{K}^{+}$channel activator (1-ethyl-2-benzimidazolinone [EBIO]): cellular electrophysiological and mechanical studies. Circulation. 2006;114(Suppl II):1790.

29. Burnham MP, Bychkov R, Félétou M, Richards GR, Vanhoutte PM, Weston AH, et al. Characterization of an apamin-sensitive small-conductance $\mathrm{Ca}^{2+}$-activated $\mathrm{K}^{+}$channel in porcine coronary artery endothelium: relevance to EDHF. $\mathrm{Br}$ J Pharmacol. 2002;135:1133-43.

30. Bychkov R, Burnham MP, Richards GR, Edwards G, Weston AH, Félétou M, et al. Characterization of a charybdotoxin-sensitive intermediate conductance $\mathrm{Ca}^{2+}$-activated $\mathrm{K}^{+}$channel in porcine coronary endothelium: relevance to EDHF. Br J Pharmacol. 2002;137:1346-54.

31. Weston AH, Absi M, Ward DT, Ohanian J, Dodd RH, Dauban P, et al. Evidence in favor of a calcium-sensing receptor in arterial endothelial cells: studies with calindol and Calhex 231. Circ Res. 2005;97:391-8.

32. Ge ZD, He GW. Comparison of University of Wisconsin and St Thomas' Hospital solutions on endothelium-derived hyperpolarizing factor-mediated function in coronary micro-arteries. Transplantation. 2000;70:22-31.

33. Ge ZD, Zhang XH, Fung PC, He GW. Endothelium-dependent hyperpolarization and relaxation resistance to $\mathrm{N}(\mathrm{G})$-nitro-l-arginine and indomethacin in coronary circulation. Cardiovasc Res. 2000;46:547-56.

34. Ledoux J, Werner ME, Brayden JE, Nelson MT. Calcium-activated potassium channels and the regulation of vascular tone. Physiology (Bethesda). 2006;21: 69-78.

35. Syme CA, Gerlach AC, Singh AK, Devor DC. Pharmacological activation of cloned intermediate- and small-conductance $\mathrm{Ca}(2+)$-activated $\mathrm{K}(+)$ channels. Am J Physiol Cell Physiol. 2000;278:C570-81.

36. Strøbaek D, Teuber L, Jørgensen TD, Ahring PK, Kjaer K, Hansen RS, et al. Activation of human IK and SK Ca ${ }^{2+}$-activated $\mathrm{K}^{+}$channels by NS309(6,7dichloro-1H-indole-2,3-dione 3-oxime). Biochim Biophys Acta. 2004;1665:1-5.

37. Yang Q, Ge ZD, Yang CQ, Huang Y, He GW. Bioassay of endothelium-derived hyperpolarizing factor with abolishment of nitric oxide and the role of gap junctions in the porcine coronary circulation. Drug Dev Res. 2003;58:99-110.

38. Weston AH, Félétou M, Vanhoutte PM, Falck JR, Campbell WB, Edwards G. Bradykinin-induced, endothelium-dependent responses in porcine coronary arteries: involvement of potassium channel activation and epoxyeicosatrienoic acids. Br J Pharmacol. 2005;145:775-84.

39. Wu M, Dong YY, Yang Q, Yim AP, He GW. Cellular electrophysiological and mechanical effects of celsior solution on endothelial function in resistance coronary arteries. Transplantation. 2005;80:1765-72. 


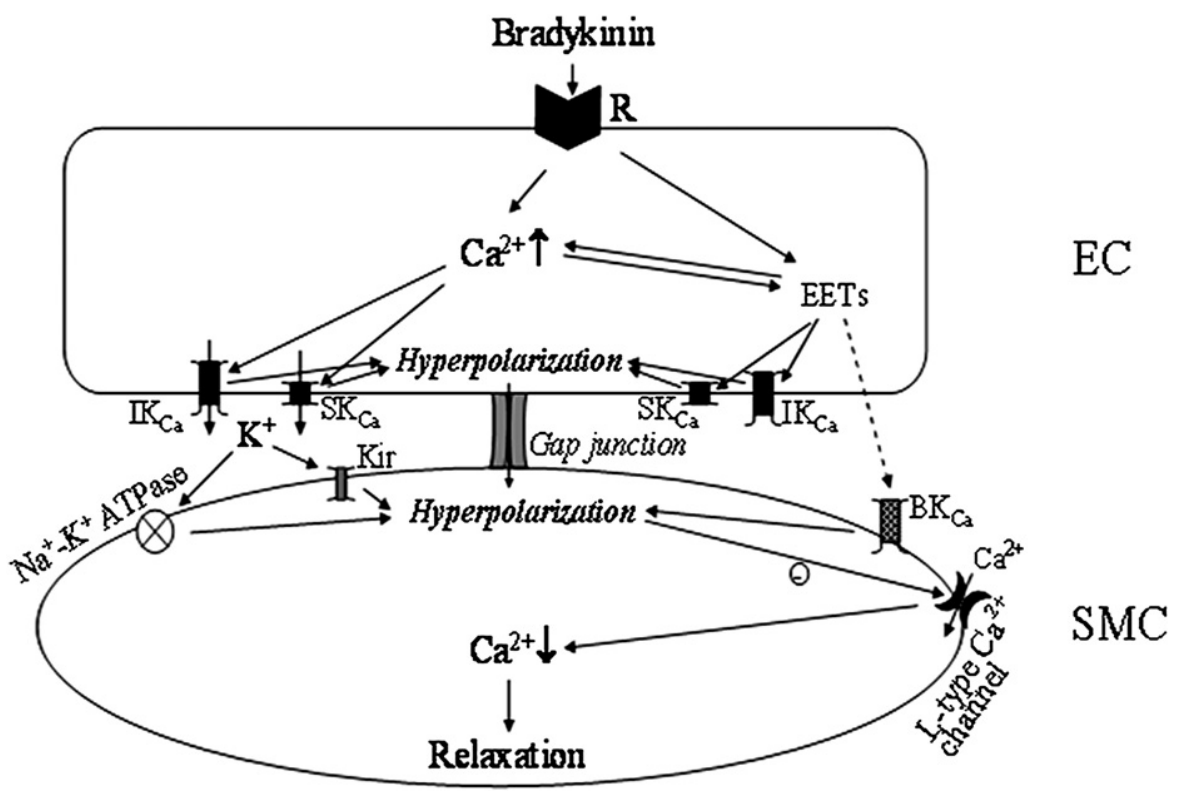

FIGURE E1. Schematic diagram describing the role of $\mathrm{IK}_{\mathrm{Ca}}$ and $\mathrm{SK}_{\mathrm{Ca}}$ in the EDHF pathway. In response to the agonist bradykinin, $\left[\mathrm{Ca}{ }^{2+}\right]_{\mathrm{i}}$ rises in endothelial cells $(E C)$ that leads to the release of $\mathrm{NO}, \mathrm{PGI}_{2}$, and other substances that can hyperpolarize the endothelial as well as the smooth muscle cell (SMC) such as $\mathrm{K}^{+}$and epoxyeicosatrienoic acids (EETs)—so-called EDHFs. The opening of $\mathrm{IK}_{\mathrm{Ca}}$ and $\mathrm{SK}_{\mathrm{Ca}}$ of the EC leads to a number of physiologic consequences. For example, $\mathrm{K}^{+}$outflows from these channels and stimulates the inward rectifier potassium channel $(\mathrm{Kir})$ and $\mathrm{Na}^{+} \mathrm{K}^{+}$-adenosine triphosphatase of the $\mathrm{SMC}^{7}$ to induce hyperpolarization of the SMC. On the other hand, other substances such as EETs may also open the endothelial $\mathrm{IK}_{\mathrm{Ca}}$ and $\mathrm{SK}_{\mathrm{Ca}}$ to induce hyperpolarization of the EC. ${ }^{38}$ The endothelial hyperpolarization may electronically transfer to SMC through the myoendothelial gap junctions to lead hyperpolarization of the SMC. EETs also open the large conductance calcium-activated potassium channel $\left(B K_{C a}\right)$ of SMC that also hyperpolarizes the SMC. ${ }^{38}$ The hyperpolarization of SMC reduces the $\left[\mathrm{Ca}^{2+}\right]_{\mathrm{i}}$ and causes relaxation. $I K_{C a}$, Intermediate conductance calcium-activated $\mathrm{K}+$ channels; $S K_{C a}$, small conductance calcium-activated $\mathrm{K}^{+}$channels; $E D H F$, endothelium-derived hyperpolarizing factor. 